\title{
AN ERROR ANALYSIS ON ENGLISH GERUNDS MADE BY THE SIXTH SEMESTER STUDENTS OF ENGLISH EDUCATION STUDY PROGRAM OF UNIB IN THE ACADEMIC YEAR OF 2017/2018
}

\author{
Recci Nuzirwan \\ University of Bengkulu \\ reccinuzirwan1014@gmail.com \\ Imranuddin \\ University of Bengkulu \\ imranulama@gmail.com \\ Arasuli \\ University of Bengkulu \\ arasuli.msi@gmai.com
}

\begin{abstract}
ABSTRAK
Penelitian ini bertujuan untuk mengetahui jenis-jenis kesalahan dan kesalahan yang paling sering muncul dalam penggunaan gerunds (sebagai subyek dari kalimat, sebagai obyek preposisi atau setelah preposisi, sebagai obyek langsung dari kata kerja tertentu, setelah ekspresi khusus, dan sebagai bentuk pasif) yang dilakukan oleh mahasiswa semester enam program studi pendidikan bahasa Inggris UNIB di tahun ajaran 2017/2018. Sampel dari penelitian ini terdiri dari 77 mahasiswa. Penelitian ini menggunakan metode deskriptif kuantitatif. Hasil dari analisi menunjukkan bahwa mahasiswa membuat kesalahan di kelima tipe gerunds. Ada $27.1 \%$ (809) kesalahan dalam penggunaan gerund sebagai obyek langsung dari kata kerja tertentu, 24.5\% (735) kesalahan dalam penggunaan gerund sebagai bentuk pasif, 20.8\% (624) kesalahan dalam penggunaan gerund setelah ekspresi khusus, $15.5 \%$ (463) kesalahan dalam penggunaan gerund sebagai obyek preposisi atau setelah preposisi, $12.1 \%$ (361) kesalahan dalam penggunaan gerund sebagai subyek dari kalimat. Jadi, kesalahan yang paling sering dilakukan oleh mahasiswa adalah gerund sebagai obyek langsung dari kata kerja tertentu.
\end{abstract}

Kata kunci : Kesalahan, Gerund

\begin{abstract}
The objectives of this research are to find out the types of errors and the most dominant error of using gerunds (as a subject of a sentence, as an object of preposition or after preposition, as a direct object of certain verbs, after a special expression and as a passive form) by the sixth semester students of English Education Study Program of UNIB in the academic year of 2017/2018. The sample of this research consisted of 77 students. This research used descriptive quantitative method. The result of the analysis shows that the students made errors in all five types of gerunds. There were $27.1 \%$ (809) errors of using gerund as direct object of certain verbs, $24.5 \%$ (735) errors of using gerund as passive form, $20.8 \%$ (624) errors of using gerund after special expression, $15.5 \%$ (463) errors of using gerund as object of preposition or after preposition, $12.1 \%$ (361) errors of using gerund as subject of a sentence. Evidently, the most dominant errors made by the students of using gerund were the gerunds as direct object of certain verbs.
\end{abstract}

Keyword : Error, Gerund 


\section{INTRODUCTION}

According to Brown (2001:362) Grammar tell us how to construct a sentence and discourse rules tells us how to string those sentence. One aspect of grammar that the students still find it difficult is about the uses of gerunds. It is because the students only learn gerund in English. The differences between two languages cause problems to students (Tarigan, 2009:5).

In Indonesian language the students do not learn about a verb with form -ing which is used as a noun, called gerund (Azar, 2009:301). The gerund looks exactly the same as a present participle (Duffley, 2006:2). Gerund and infinitive also leads into confusion.

As students of English Education Study Program of UNIB, gerund actually has been taught in fourth semester as a part of structure three. Since, they were stayed at faculty of teacher training and education, they were trained to be a teacher. Teacher must has a correct grammar in the process of teaching and learning.

In fact, based on the researcher's experience when she studied gerund most of the students get confused and considered gerund as complicated material. On top of that, it is inspired her to do this research. In Addition, after informal interview with some students from class $A$ and $B$, the researcher found that the students are confused when they make sentences using gerund. Most of the student's usually only change the sentence from Indonesian language into English without looking at the grammar. They often make a mistake when they differentiate verb -ing forms as a gerund and a participle. It usually happens because they do not know how to identify a noun, an adjective, or even a verb in a sentence in which a gerund and a participle can be differentiate with it. They also make mistakes using both in sentences. For example, playing badminton is very entertaining (Azar, 2009). In this case the students tend to construct play badminton is very entertain (Azar,2009). They are not aware that the sentence is incorrect. They should make play as gerund of subject and entertain as adjective. Therefore, play should be playing and entertain should be entertaining. So, subject and object is agreement.

Furthermore, they make an error of using each function of gerunds. Sometimes the students are also confused of differentiating between gerund and to infinitive for instance, they use infinitive when the sentence need gerund. For example: I suggested going to dinner. I suggested to go to dinner (Azar,2009:345). Sentence one with the gerund is correct because you can only use gerund after the verb suggest (Azar, 2009: 307). Most students do not realize that they make an error of using gerund because gerund has many functions in a sentence. The students do not know in what functions of gerund they often make an error. The general errors of many students are because they can not distinguish of an -ing form in gerund usage. There are many kinds of -ing forms in English (Duffley, 2006: 5). This condition is making confusion for students in learning about an -ing form, especially for gerund. The students have tendency to think about -ing form in gerund is a tense usage of participle. Both a gerund and a participle come from a verb, and both end in-ing (Azar, 2009). However, each has a different function. A gerund acts like a noun while a participle acts like a verb or adjective (Eastwood, John. 2002:160). For example, what an amazing movie! I want to watch it again! (Duffley, 2006). The -ing form in the sentence is participle function as an adjective. They have been studying for a long time and want to take a break. The -ing form in studying is participle function as a verb. He cares about getting a good job. The -ing form in getting is a gerund act like a noun (Azar, 2009).

In this case, most of the students are not aware yet of the importance of gerund function in English language. Their awareness for using gerund is less. The students should know gerund can be mastered and it is very important for them to understand the gerund. The understanding of the gerund, of course would be very helpful for them to construct sentences either written or spoken. It means 
gerund is very important aspect in speaking and writing skill.

This research also supported by three previous studies. The first study from Nurmawaddah (2014) with the title An Error Analysis on Using Gerund Made by the Students (A Study toward the Third Grade of Senior High School 4, Cimahi Academic Year of 2014/2015). The result showed that the dominant error made by the students was the use of gerund in using direct object which occurred 189 times (63\%) that caused by the students limitedness in memorizing the certain words followed by gerund.

The second study from Dita (2014) was about An Error Analysis in Using Verb-Ing Forms (A Case Study at the Eleventh Year Students of SMA Darul Muttaqin) and the third from Amelia Siska with the title An Error Analysis On The Use Of Gerund Made By The Eleventh Grade Students Of SMA Free Methodist Medan. Both studies found that the most dominant error is Omission Error.

Based on the problem and the phenomena above the researcher feels important that the research entitled "An Error Analysis of English Gerunds Made by The Sixth Semester Students of English Education Study Program of UNIB in The Academic Year of 2017/2018" is needed to conduct.

\section{METHOD}

This research used descriptive quantitative. In quantitative method, the researcher tried to find out types of error and the most dominant error made by the sixth semester students of English Education Study Program of UNIB in the academic year of $2017 / 2018$ in using gerund. According to Creswell (2014:42), the descriptive analysis means to gather information about the present existing condition.

The population in this research is the sixth semester students of the English Education Study Program of UNIB in the academic year of 2017/2018 consisted of class $A$ and $B$ with the total of 77 students.

All of the population will be the subject of the research. It is based on theory by Arikunto (2006:134) that if the subject less than 100, it's better to take all.
The researcher used test as the instrument of the research in order to get the data. Arikunto (2006:150) stated test is some questions or exercise and an instrument that used for measuring the skill, the knowledge of intelligence, ability or talent possessed by individual or group. The test consisted of multiple choices, true/false, matching the verbs and completing the sentences. The test questions consisted of 100 items.

The are some procedures in the data analysis. First, making questions for the test. Second, giving the test. Third, collecting the answer sheet. Fourth, analyzing the data. After the data was classified by putting it into the table. It consisted number of the students and the five types of gerunds. The number of errors made by the students were counted by the researcher. To find out the percentage of the error in using gerunds made by the students, the researcher used distribution frequency relative or descriptive analysis technique (percentage) formula. This was adopted from Allan G. Bluman :

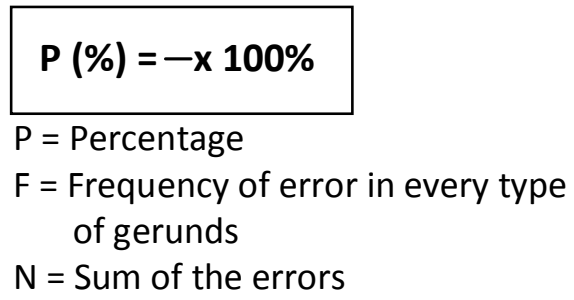

Every type of error which found out on the test was described and classified based on every function of gerunds such as gerund as subject, gerund as object of preposition or after preposition, gerund as direct object of certain verbs, gerund after special expression and gerund as passive form. After that the most dominant error was found out. Then the result was described with other findings which had been found by another researcher in previous studies.

\section{RESULTS AND DISCUSSION \\ Results}

\section{Types of Error in Using Gerunds}

Research question number 1 asked about types of error in using gerunds. The researcher found that the students made errors in using five types of gerunds. They were gerunds as direct object of certain verbs or D.O, gerund as passive form or Pass, 
gerund after special expression or S.E, gerund as object of preposition or $\mathrm{P}$ and gerund as subject of a sentence or $\mathrm{S}$.

Table 1. The Result of Error in Using Gerunds

\begin{tabular}{|l|l|l|l|l|}
\hline No. & $\begin{array}{l}\text { Type } \\
\text { s }\end{array}$ & $\begin{array}{l}\text { Amount } \\
\text { of } \\
\text { Question } \\
\text { item }\end{array}$ & $\begin{array}{l}\text { Frequenc } \\
\text { y of Error }\end{array}$ & (\%) \\
\hline 1. & D.O & 20 items & 809 & $27.1 \%$ \\
\hline 2. & Pass & 20 items & 735 & $24.5 \%$ \\
\hline 3. & S.E & 20 items & 624 & $20.8 \%$ \\
\hline 4. & P & 20 items & 463 & $15.5 \%$ \\
\hline 5. & S & 20 items & 361 & $12.1 \%$ \\
\hline \multicolumn{2}{|l}{ Total errors } & 2992 & \\
\hline
\end{tabular}

The Most Dominant Errors in Using Gerunds

To find out the percentage of the error in using gerund made by the students, the researcher used a simple formula adopted by Allan G. Bluman. Based on table 1, the sum of the total errors made by the students was 2992 errors. The most dominant error made by the students of the sixth semester of English Education Study Program of UNIB in the academic year of 2017.2018 of using gerunds was gerund as direct object of certain verbs with the frequency 809 errors or $27.1 \%$ . The second was gerund as passive form with the frequency 735 errors or $24.5 \%$. The third was gerund after special expression with the frequency 624 errors or $20.8 \%$. Then the fourth was gerund as object of preposition or after preposition with 463 errors or $15.5 \%$ and the fifth was gerund as subject of a sentence with the frequency 361 errors or $12.1 \%$.

\section{Discussion}

\section{Types of Error in Using Gerunds}

There were similarities between this research result and Nurmawaddah (2014). The objective was to find out types of error in using gerunds. However Nurmawaddah (2014) analyzed three types of gerunds while this research analyzed five types of gerunds. In gerund as a subject of a sentence, the students actually have known how to apply the subject properly. $\mathrm{V}$ +ing in the beginning of the sentence called gerund, almost every students know how to use it. The errors occurred because incomplete application of rules. Incomplete application of rule covers students' failure to apply the rule completely.
Another previous study from Dita (2014) found that the reason of the students made errors because ommisson of the verb -ing form. It means that the students used simple verb form instead of verb -ing form. She stated that the students confused in forming the verb as a subject/object or main verb in the sentence. Another reasons of students' error was the ignorance of rule restriction. The learner failed to observe the restriction of existing structures.

The students made errors in using gerunds as object of preposition with the frequency 463 errors. The errors occurred because the ignorance of rule and incomplete application of rule. Cambrige stated that while the students might have trouble remembering the correct preposition to use in any given context, they can confidently use a gerund after any preposition. Therefore, it proved that almost half of the students did not know that every preposition must be followed by gerund.

In using gerund as direct object of certain verbs the students made error because they did not memorized verbs that must be followed by gerund.

Numawaddah (2014) did not analyze gerund after special expressions and gerund as passive form. The researcher found that the students also made error of using gerund after special expression and gerund as passive form. The students did not remember some expressions which had to be followed by gerund such as have fun/ a good time, have trouble/difficult, have a hard time/difficult time, spend + expression of time or money, waste + expression of time or money, sit + expression of place, stand + expression of place, lie + expression of place, find + (pro) noun, catch + (pro) noun, Azar (2009:304). Most students made errors of using gerund after special expression because they did not recognize those expression which should be followed by gerund.

The students also made errors in using gerund as passive form. Mostly the students answer the question by replacing gerund with infinitive or passive form. 


\section{The Most Dominant Errors in Using Gerunds}

In this research, the most dominant errors made by the students was gerund as direct object of certain verbs. The students did not memorized certain verbs which should be followed by gerund. The differences of Indonesian language and English made the students did not notice the certain verbs followed by gerund. They thought there were no rule in using verbs in English. Almost all students made errors in the same cases. They answered the questions by using infinitive verb (to + verb) and original verb (verb 1 ).

Most students made the errors because they ignored the rules by choosing the answer infinitive verb, verb1, past tense, and else. They made the errors in gerund as direct object of certain verbs because they thought that after the verbs enjoy, forget, consider, postpone, resist, can not help, mind, stop, remember, deny, finish and suggest were followed by infinitive verb.

Similar to finding summarized by Nurmawadah (2014) who also found that gerund as direct object of certain verbs was the most dominant error in using gerund. It's difficult for the students to understand the second language. The limitation of remembering the certain verbs used by gerund was so hard, they have a problem to recognize many verbs which needed to be followed by gerund. In this research the students did not look at the grammar. Sometimes students knew the tenses but did not know the grammar, so the students just focused on looking at the tenses, but they neglected the others grammar that they should have known. Therefore, the students made errors in using gerunds especially gerund as direct object of certain verbs. Notably it became the most dominant error among the gerunds.

\section{CONCLUSION AND SUGGESTION \\ Conclusion}

Based on the results and the discussion in the previous chapter, in can be concluded that all of the respondents seems to made errors in all five types of gerunds (as a subject of a sentence, as a direct object of preposition, as a direct object of certain verbs, after special expression and as a passive form. However, the majority of the respondents made errors in using gerund as direct object of certain verbs. This result confirmed by previous study from Nurmawaddah (2014).

\section{Suggestion}

The students should practice and doing more exercises related to gerunds.

The lecturers have to find effective technique or strategy in teaching gerunds. Furthermore, the students should be given more exercises.

Future researcher is expected to do classroom action research to find effective technique in order to diminish students' errors in using gerunds.

\section{REFERENCES}

Arikunto, Suharsimi. 2006. Prosedur Penelitian: Suatu Pendekatan Praktik (Edisi Revisi VII). Jakarta: PT. Melton Putra.

Amelia, Siska. 2014. An Error Analysis on the Use of Gerund Made by the Eleventh Grade Students of SMA Free Methodist Medan. Medan: University of Sumatra Utara

Azar, B.S. 2009. Understanding and Using English Grammar (4 ${ }^{\text {th }}$ Edition). Englewood Cliffs, New Jersey: Prentice-Hall, Inc.

Bluman, Allan G. 2004. Elementary Statistics: A Step by Step Approach, $5^{\text {th }}$ edition. New York: The McGraw Hill Companies, Inc.

Brown, Doughlas, H. 2001. Teaching by Principles An Interactive Approach to Language Pedagogy ( $2^{\text {nd }}$ Edition). London : Longman.

Creswell, John W. 2014. Research Design: Qualitative and Quantitative and mixed methods Approaches (4 ${ }^{\text {th }}$ Edition). California: Sage Publication.

Duffley, J. Patrick. 2006. The English GerundParticiple, A Comparison With the 
Infinitive. New York: Peter Lang Publishing.

Eastwood, John. 2002. Oxford Guide to English Grammar ( $7^{\text {th }} \quad$ Impression). Oxford: Oxford University Press.

Fatwa, Dita. 2014. An Error Analysis In Using Verb-Ing Forms (A Case Study At the Eleventh Year Students of SMA Darul Muttaqin). Jakarta: Syarif Hidayatullah State Islamic University.

Celentano, Thomas. 2013. English Gerunds and Infinitives for ESL Learners $\left(2^{\text {nd }}\right.$ Edition). New York: Pearson Education.

Harmer, Jeremy. 2001. The Practical of English Language Teaching ( $3^{\text {rd }}$ Edition). Essex: Pearson Education Limited.

Kolln, Martha and Robert Funk. 2012. Understanding English Grammar $\left(9^{\text {th }}\right.$ Edition). New York: Pearson Education.

Murphy, Raymond. 2012. English Grammar in Use (4 ${ }^{\text {th }}$ Edition). Cambridge: Cambridge University Press.

Norrish, J. 1983. Language Learners and Their Errors. London : Macmillan.

Nurmawaddah. 2014. An Error Analysis of Using Gerund Made by the Students. Bandung : Pasundan University.

Payne, Thomas Edward. 2011. Understanding English Grammar. New York: Cambridge University Press.

Richards, C.J., \& Schimidt, R . 2002. Longman Dictionary of Language Teaching and Applied Linguistics (4 $4^{\text {th }}$ Edition). London: Longman Group Limited.

Saleh, M. 2001. Pengantar Praktik Penelitian Pengajaran Bahasa. Semarang : IKIP Semarang Press
Scrievener, J. 2004. Teaching Grammar(Oxford Basics). Oxford: Oxford University Press.

Tarigan, H. G. 2009. Pegajaran Analisa Konstrastive Bahasa. Bandung: Angkasa.

Thomson, A. J., and A.V. Martinet. 1986. A Practical English Grammar. New York: Oxford University Press Walton Street.

Thornbury, Scott. 2002. How To Teach Grammar (4 ${ }^{\text {th }}$ Impression). England: Pearson Education.

Walliman, Nicholas. 2011. Research Methodes: The Basic. Madison Avenue, New York: Routledge.

Williams, Marion and Tony Wright. 2009.A Course in Langauge Teaching. Cambridge, New York:Cambridge University Press 